\title{
Power plant ash and slag waste management technological direction when Kansk-Achinsk brown coal is burned
}

\author{
Snejana A. Lihach ${ }^{1 *}$, Roman N. Kulesh ${ }^{1}$, Valentina I. Nikolaeva ${ }^{1}$, Ksenia Y. Orlova ${ }^{1}$, and \\ Aygul S. Ilyasova ${ }^{1}$ \\ ${ }^{1}$ National Research Tomsk Polytechnic University, 634050 Tomsk, Russia
}

\begin{abstract}
Today resource efficiency technology development in all industries where conventional raw material is being replaced by local natural resources and industrial waste is an essential matter. Along with that most producing operations are overload with wide range of waste produced during technological process. Thermal power stations are real world evidence. Their main waste is ash and slag which accumulated in great amounts in often overfull ash dumps. The goal of present work is to find perspective ash dump waste utilization methods. The study will be based on experimentally obtained data: elementary compound and properties of Kansk-Achinsk brown coal. Research methods: experimental, chemical silicate analysis, mineralogical forms identification within samples by using ASM X-ray diffraction analysis. Experiments resulted with the following conclusions: silica is ash main component, and ash has the form of ore concentrate analogy in a number of elements. We think that ASM main properties which make it useful for utilization are: high content of calcium oxide; high ash sorption properties; ASM radiation safety class which makes them safe to be used in materials, goods, and structures production for residence and public buildings construction and reconstruction; sufficiently high content of individual elements.
\end{abstract}

\section{Introduction}

Yearly Russian power industry produces not only electric energy, but also about 27 million tons of ash and slag waste (ASW). Just a small part of it, less than 15 percent, is reprocessed in other industries [1]. The main part of the waste is stored for years in ash dumps which take prime quality lands and deteriorate ecology. In past years several cities start really feel the problem: power plants built outside cities in due course time appeared to be within the city limits (Tomsk, Kemerovo, Belovo, Novosibirsk).

Meanwhile coal solid part and its components might become a huge source of raw materials and be widely applied in some industries [2]. Therefore problems of ASW common usage in construction materials manufacturing, construction and other industries are essential.

* Corresponding author: korotkikh@tpu.ru 


\section{Ash and slag research}

In order to determine ASW line of utilization we need to perform a number of studies. An ash and slag materials (ASM) passport is put together based on the studies as a product of a power plant. Then the decision is made how an ASM will be utilized. A difference between ASM and ash dump is that an ASM is a classified product with physical-chemical and granulometric properties which concur with specifications. ASM elementary and compound constitutions are needed to be specified in order to determine whether or not ASM could be used as a raw material. The constitutions are based on many factors which determined by coal burning conditions and boiler operating regime. Consequently ASM passport should contain a possible range of products desired parameters [3].

In line with the above ash and slag elementary composition and properties study was per-formed for Kansk-Achinsk brown coal burning. The study was pursued in several stages: first ash and slag sampling from a boiler and ASM sampling from the ash dump were made; then laboratory studies were performed. Ash and slag samples were taken from working boilers with bottom-ash and slag-tap removal. All sampling work, samples preparation and study were performed in compliance with standard technique.

We obtained percentage ranges of elements content calculated using oxides by elementary composition research. The results are presented in table 1.

Table 1. Percentage ranges of elements content

\begin{tabular}{|c|c|c|c|}
\hline \multirow{2}{*}{$\begin{array}{c}\text { Elements content calculated } \\
\text { using oxides }\end{array}$} & \multicolumn{3}{|c|}{ Range, $\%$} \\
\cline { 2 - 4 } & Ash & Slag & Ash and slag mixture \\
\hline Ignition loss & $0.07-0.18$ & - & below 10 \\
\hline $\mathrm{SiO}_{2}$ & $32.97-48.01$ & $41.05-49.16$ & $49.23-65.79$ \\
\hline $\mathrm{TiO}_{2}$ & $0.27-0.48$ & $0.27-0.31$ & $0.32-0.55$ \\
\hline $\mathrm{AL}_{2} \mathrm{O}_{3}$ & $6.25-9.01$ & $5.89-7.41$ & $7.08-10.14$ \\
\hline $\mathrm{Fe}_{2} \mathrm{O}_{3}$ & $10.78-15.94$ & $15.23-19.05$ & $6.29-18.1$ \\
\hline $\mathrm{CaO}^{\mathrm{MgO}}$ & $26.7-33.9$ & $20.6-25.07$ & $10.2-21.4$ \\
\hline $\mathrm{K}_{2} \mathrm{O}$ & $5.15-7.09$ & $3.39-4.29$ & $2.32-6.45$ \\
\hline $\mathrm{Na}_{2} \mathrm{O}$ & $0.2-0.3$ & $0.2-0.5$ & $0.2-0.42$ \\
\hline $\mathrm{SO}_{3}$ & $0.3-0.6$ & $0.35-0.6$ & $0.2-0.4$ \\
\hline $\mathrm{CaO}_{\text {free }}$ & $1.31-2.12$ & $0.48-2.12$ & $0.48-1.47$ \\
\hline & $6.5-9.7$ & нет & $0.14-0.98$ \\
\hline
\end{tabular}

We paid attention to the fact that ash and slag mixture from ash dump has large weight loss value. It might be explained by intrusion of coal dust into an ash sluiceway in a boiler shop. Besides, supply of organic substance into an ash dump from the outside is possible as well. Also, we should take into consideration chemical reactions which take place when ash and slag waste is stored in a waterlogged ash dump.

For the purpose of ASM content research we performed chemical silicate analysis and ASM X-ray diffraction analysis. The last one let us to identify mineralogical forms within samples.

\section{Results and discussion}


Based on the research findings we obtained percentage ranges of elements content calculated using oxides with Kansk-Achinsk coal burning based on fly ash, slag and stored ash and slag mixture. Using the obtained results we made the fol-lowing conclusion:

1. The ash samples from under multicyclones appear to be amorphized textural features with finely dispersed physical mixture of some crystalline phases. Low temperature $\beta-$ quartz $(\beta-\mathrm{SiO} 2)$ of hexagonal syngony is the largest comparing masses. Overall researched ash samples contain from 33 to 10 weight $\%$ of $\beta-\mathrm{SiO}_{2}$. The second crystalline structural constituent of ash samples is caustic limestone $(\mathrm{CaO})$. The samples contain from 8 to 18 weight $\%$ of $\mathrm{CaO}$ as well as from 4 to 16 weight $\%$ of anhydrite (anhydrous plaster, CaSO4). All ash samples are magnetic and contain cryptocrystalline magnetic fraction in form of spinel magnetite (Fe3O4). There are from 11 to 22 weight $\%$ of free iron crystalline oxide in the form of hematite $\left(\alpha-\mathrm{Fe}_{2} \mathrm{O}_{3}\right)$ and magnetite.

2. Slag samples in case of wet bottom operation are appeared as glass-like amorphized mass. X-ray diagrams show geometric feature short range ordering of $\mathrm{Si}-\mathrm{O}$ atoms and specific weak reflections which are typical for low temperature $\beta$ - quartz $\left(\beta-\mathrm{SiO}_{2}\right)$. Slag samples are magnetic.

3. Slag samples in case of bottom-ash removal mainly consist of high-silica sand in form of low temperature $\beta$ - quartz $\left(\beta-\mathrm{SiO}_{2}\right)$, and also in form of hydrosilicic acid complex salts - calcium and magnesium silicates - type $\mathrm{CaO} \cdot \mathrm{SiO}_{2}, \mathrm{CaO} \cdot \mathrm{MgO} \cdot 2 \mathrm{SiO}_{2}$, $2 \mathrm{CaO} \cdot \mathrm{MgO} \cdot 2 \mathrm{SiO}_{2}$. Quantity of $\beta-\mathrm{SiO}_{2}$ in samples is from 27 to 66 weight $\%$. Calciferous magnesia siliciferous components (calcium and magnesium silicates) are from 18 to 560 weight $\%$.

4. Average ash dump sample analysis showed that it contains 70 weight $\%$ of silicon dioxide, 27 weight $\%$ of cementitious component in form of calcium silicates, magnesium silicates and plaster, and about 3 weight $\%$ of free iron oxides.

Therefore, produced waste has heterogeneous chemistry, but it is identical in a large part with natural mineral raw materials.

Construction industry is the main line of power stations fuel combustion waste utilization $[4,5]$.

First of all the waste could be used as a bulk material for automobile road border levees regulated by industry document [6]. Nowadays border levees are formed with sand and gravel mixture, which is quarried with open-pit method. This method in most cases leads to ecological damage of a region with lakes and wetlands formation in site of opencast mines. As shown above ASW is identical with natural silicate compounds which are generally used in this industry.

Secondly, ASW is used for heavy weight concrete, light weight concrete and mortars production for the purpose of concrete and fillers cost-effectiveness, concrete and mortar mixture properties quality level improvement. Ashes which contain no less than $30 \%$ of $\mathrm{CaO}$ are used as a matrix for lime and concrete partial replacement in autoclaved and nonautoclaved lightweight concrete.

In accord with [7] calcium oxide content by weight should be no more than $10 \%$ - in the researched samples it is higher. $\mathrm{CaO}_{\text {frree }}$ content no more than $5 \%$ for cell concrete is not normative - in the samples it is no more than $9.7 \%$. Sulphur and Sulphur oxide compounds content in terms of the equivalent amount of $\mathrm{SO}_{3}$ is no more than $6 \%$ - in the samples it is $2.21 \%$. MgO content is no more than $5 \%$, in the samples $-7.09 \%$, but it is acceptable for $\mathrm{MgO}$ content to be higher in some cases: if samples soundness is given during auto-clave test; if these ashes application is based on concrete lifetime advanced studies with consideration of specific application conditions. $\mathrm{Na}_{2} \mathrm{O}$ con-tent is no more than $3.5 \%$, in the samples $-2.12 \%$. Ignition weight loss is no more than $5 \%$. The same parameter for ash and slag mixture is exceeded. It is important to mention that marginal excess of tested parameters is possible to level during production by adding a neutral material. 
Today resource efficient technology engineering is a topic of immediate interest in all industries where traditional imported raw material is being replaced by local natural resources and industrial waste.

The conducted research shows that according to elementary, granulometric and mineral composition Kansk-Achinsk coal ASM is mostly identical to natural raw material. It is possible to use ash as a raw material for rare elements recovery [8]. It is found that there are over 50 such elements in ash and slag, what let to reduce expenses for crude ore geological survey. ASM contains aluminium, silicon, calcium and ferrum compounds in such quantities which are of some real interest. Besides, there is an important problem of the following toxic elements control in ash and slag: $\mathrm{Li}, \mathrm{Ba}, \mathrm{Ga}, \mathrm{B}, \mathrm{Cu}, \mathrm{Ag}, \mathrm{Cd}, \mathrm{Hg}, \mathrm{Pb}$ [9].

Non-ferrous metals of value might be re-claimed from ASM as a part of a complex process, when main part of ASM is utilized to give construction materials, stonecast products and other.

We undertook the study in order to evaluate possibility to quarry some particular elements from Kansk-Achinsk coal ash. Table 2 represents the results of the study.

Table 2. Content of some chemical microelements in Kansk-Achinsk coal ash.

\begin{tabular}{|l|c|}
\hline \multicolumn{1}{|c|}{ Descriptor } & Weight percent, \% \\
\hline Potassium & 0.23 \\
\hline Titanium & 0.22 \\
\hline Barium & 0.016 \\
\hline Chromium & 0.0028 \\
\hline Cobalt & 0.0029 \\
\hline Nickel & 0.0063 \\
\hline Stannum & 0.011 \\
\hline Molybdenum & 0.0041 \\
\hline Stibium & 0.0008 \\
\hline Arsenium & 0.0046 \\
\hline Argentum & 0.00023 \\
\hline Zinetum & 0.0027 \\
\hline Strontium & 0.0037 \\
\hline Lead & 0.00019 \\
\hline Cadmium & 0.000077 \\
\hline Tungsten & 0.034 \\
\hline Lanthanum & 0.0012 \\
\hline Lithium & 0.0035 \\
\hline Indium & $<0.005$ \\
\hline
\end{tabular}

\section{Conclusions}

Analysis of table 1, table 2 and the con-ducted research results shows that silica is ash main component, and ash has the form of ore concentrate analogy in a number of elements. We think that ASM main properties which make it useful for utilization are: high content of calcium oxide; high ash sorption properties; ASM radiation safety class which makes them safe to be used in materials, goods, and structures production for residence and public buildings construction and reconstruction; sufficiently high content of individual elements. 


\section{References}

1. A.I. Kalachev, Power station ash and slag: disposal, transportation, utilization, storage, 5, Russian ASW market through trader's eyes. Phenix consortium (2014)

2. J. Hot, M. Sow, C. Tribout, M. Cyr, Constr. Build. Mater. 110, 218 (2016)

3. S.-W. Yoo, Y.K. Cho, S.-H. Jung, K.-M. Lee, S.-J. Kwon, J. Mater. Cycles Waste, 1 (2016)

4. N. Nordin, M.M.A.B. Abdullah, M.F.M. Tahir, A.V. Sandu, K. Hussin, Int. J Conserv. Sci. 7, 161 (2016)

5. M. Pasetto, N. Baldo, Constr. Build. Mater. 108, 112 (2016)

6. ODM 218.2.031.-2013, Methodological recommendations for power stations coal combustion fly ash, ash and slag mixtures use in road construction (2015)

7. GOST 25818-91, Thermal power station fly ashes for concrete. Specifications (2015)

8. Y.-X. Wang, L. Peng, Y. Wang, T. Zhang,H.-L. Liu, L. Mu, Huanjing Kexue/Environmental Science 37, 60 (2016).

9. L.C. Ram, R.E. Masto, N.K. Srivastava, J. George, V.A. Selvi, T.B. Das, S.K. Pal, S. Maity, D. Mohanty, Environ. Monit. Assess. 187, 14 (2015) 